\title{
An aberrant bi-apical Follicucullus (Albaillellaria) from the late Guadalupian (Middle Permian), with the possible oldest evidence of double malformation in radiolarians
}

\author{
Tsuyoshi Ito $^{1^{*}}$, Yusuke Kitagawa ${ }^{2}$ \& Atsushi Matsuoka ${ }^{3}$ \\ ${ }^{1}$ Research Institute of Geology and Geoinformation, Geological Survey of Japan, AIST, Tsukuba, Ibaraki 305-8567, Japan \\ ${ }^{2}$ Mitsubishi Material Techno Co., Tokyo 102-8205, Japan \\ ${ }^{3}$ Department of Geology, Faculty of Science, Niigata University, Niigata 950-2181, Japan \\ *Correspondence: ito-t@aist.go.jp
}

\begin{abstract}
An aberrant bi-apical Follicucullus specimen (Albaillellaria, Radiolaria) has been discovered from an upper Guadalupian (Middle Permian) chert block of the Kamiaso Unit of the Mino terrane, central Japan. If this specimen was formed with double malformation, it would be the oldest record of this phenomenon in radiolarians and the first record of its kind in Albaillellaria.
\end{abstract}

Received 11 April 2016; revised 4 July 2016; accepted 5 July 2016

Conjoined radiolarians, in which two or more individuals are joined together, are of particular interest as evidence of binary fission (e.g. Anderson \& Gupta 1998), although double malformation essentially forms during skeletogenesis. Radiolarians represent significantly different ecology and physio-ecology in different taxonomic orders (Suzuki \& Not 2015), but conjoined specimens have been widely recognized in various radiolarian orders such as Collodaria (Sugiyama 1992; Anderson \& Gupta 1998), Entactinaria (Dumitrica 2013), Nassellaria (Takahashi \& Honjo 1981; De Wever 1985; Dumitrica 2013) and Spumellaria (Itaki \& Bjørklund 2007; Dumitrica 2013). These data strongly suggest that conjoined specimens could have appeared in other orders such as Albaillellaria.

Conjoined radiolarians rarely occurred in the Mesozoic (e.g. Dumitrica 2013) and Cenozoic (e.g. Itaki \& Bjørklund 2007) and no confirmed conjoined specimens have yet been found from the Palaeozoic (Dumitrica 2013). De Wever (1985) illustrated several aberrant conjoined specimens as Siamese radiolarians from the Silurian, but these specimens, according to Dumitrica (2013), are probably bryozoan colonies.

We have discovered an aberrant bi-apical specimen of the Permian radiolarian genus Follicucullus. If this specimen formed as a result of a double malformation, it is not only the oldest record of this phenomenon in radiolarians, but may also be the first record of conjoining in the Order Albaillellaria.

\section{Material and bi-apical Follicucullus}

A Capitanian (late Guadalupian, Middle Permian) age radiolarian assemblage including Follicucullus charveti Caridroit \& De Wever and $F$. porrectus Rudenko has been obtained from a chert block (sample IT15102608) within conglomerates of the Kamiaso Unit of the Mino terrane at Awano in the Mino-Hichiso area, Gifu Prefecture, central Japan, near the locality of sample KY2014061107 of Ito et al. (2016). For detailed geological information of this area, see Ito et al. (2016).

The assemblage includes a single Follicucullus specimen with a bifurcated test on part of its pseudothorax (Fig. 1a). The right part is a typical Follicucullus test, whereas the left part is a thin cylinder of some organism (Fig. 1b). The base of this cylinder coalesces with the typical Follicucullus test, although this part is probably cracked (Fig. 1c).

\section{Implications}

Follicucullus belongs to the Order Albaillellaria, which is characterized by a triangular framework (De Wever et al. 2001). This framework is formed by three intersecting bars in order to restrict the shell morphology of late Palaeozoic Albaillellaria. The

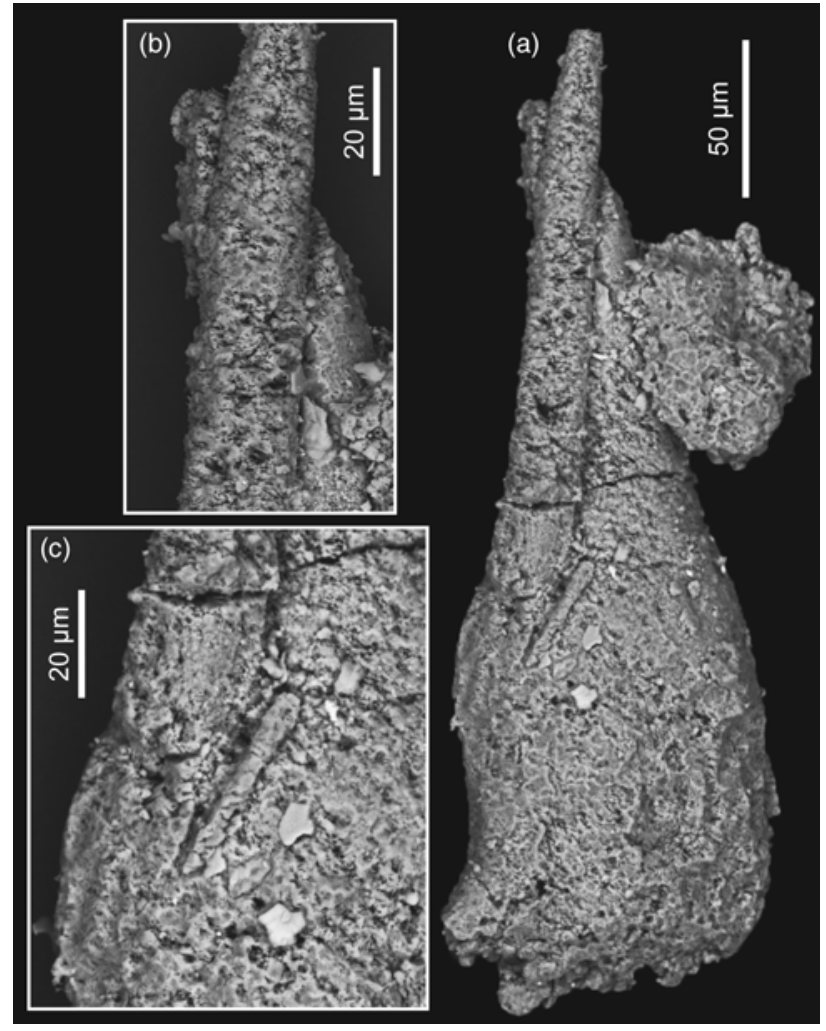

Fig. 1. Bi-apical Follicucullus from a chert block (sample IT15102608) at Awano, Mino-Hichiso area, Gifu Prefecture, central Japan: (a) whole image of bi-apical Follicucullus; (b) enlarged view of crossed two apical portions; (c) enlarged view of the base of the two apical portions. Specimen deposited in the Nanjing Institute of Geology and Palaeontology, Chinese Academy of Sciences, Nanjing, China; depositional number: 164489. 


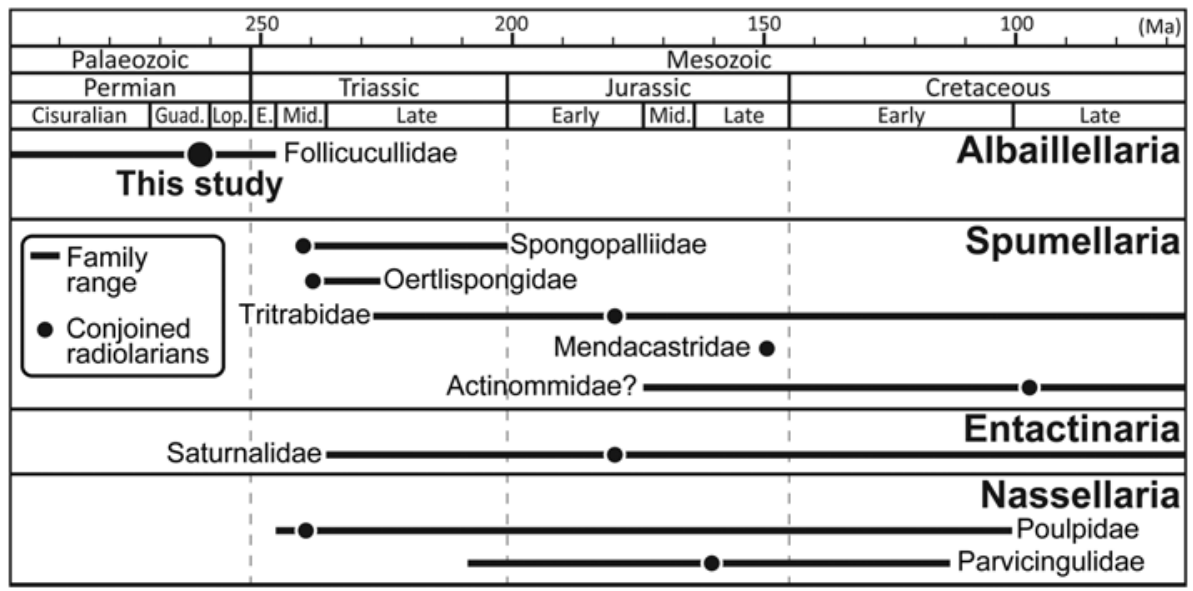

Fig. 2. Palaeozoic-Mesozoic conjoined radiolarians in the fossil record. Family classification and range are after De Wever et al. (2001); conjoined radiolarians are mainly based on De Wever (1985) and Dumitrica (2013). In most cases, only one conjoined specimen has been discovered in each family. Guad., Guadalupian; Lop., Lopingian.

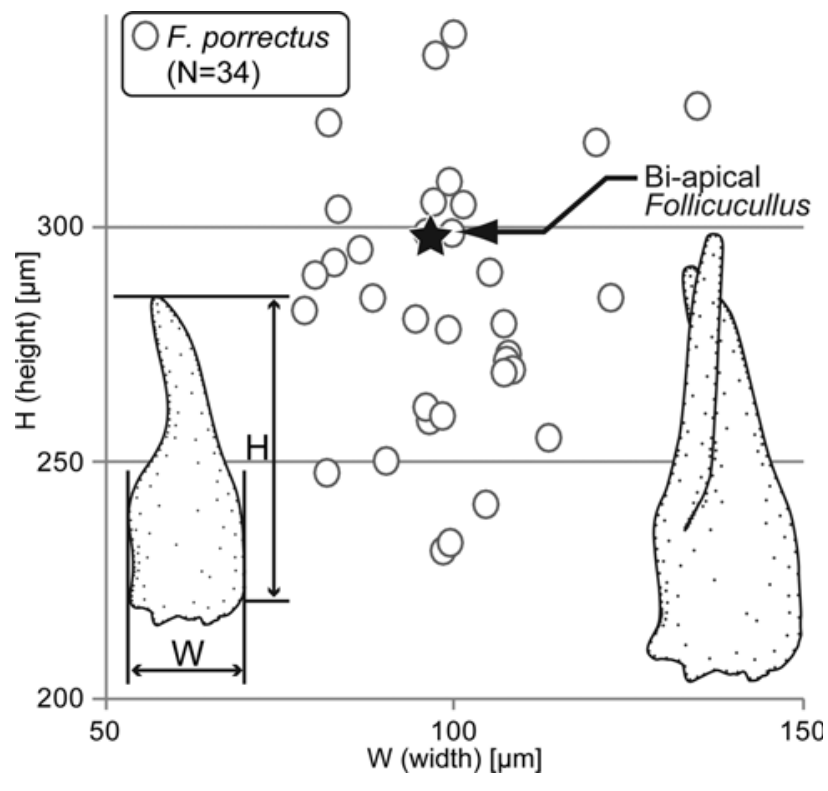

Fig. 3. Measurements of shell sizes of bi-apical Follicucullus specimen and Follicucullus porrectus Rudenko obtained from a chert block (sample IT15102608) in Awano. Note: the test size of the bi-apical Follicucullus specimen falls in the size range of $F$. porrectus, which indicates the specimen is in the fully grown stage.

framework of the Permian Follicucullus had largely retrograded, but the test morphology maintained its conical shape with two bars inside the test. This restriction constrains Follicucullus developing bi-apical members; thus, the bi-apical Follicucullus specimen is regarded as an aberrant morphotype, probably of $F$. porrectus.

One concern, however, is that the left cylinder appears to belong to an unknown species. This form may be interpreted as a hypomorphic $F$. porrectus, an unknown albaillellarian specimen, or an amalgamated siliceous fragment resulting from diagenesis. This specimen may have deformed to some extent, but diagenetic amalgamation cannot explain this joint condition on the pseudothorax. As it is impossible to evaluate whether the left part is a hypomorphic one or a different species, we suggest that it could be considered as an aberrant bi-apical Follicucullus. Regardless of its origin, the bi-apical specimen that may have originated from binary fission is the oldest certain record of its kind in radiolarians (Fig. 2).
Assuming that this form is a double malformation, the thin cylinder is regarded as $F$. porrectus. The shell size of the right test (96 $\mu \mathrm{m}$ wide and $298 \mu \mathrm{m}$ high) unquestionably falls in the size range of $F$. porrectus in terms of width $(78-135 \mu \mathrm{m}$; average: $99 \pm$ $12 \mu \mathrm{m})$ and height $(231-341 \mu \mathrm{m}$; average: $284 \pm 28 \mu \mathrm{m})$ (Fig. 3), indicating that the specimen is in the fully grown stage. The conjoined phenomenon in the fully grown stage of radiolarians can be observed in both Mesozoic and Cenozoic Nassellaria individuals that formed in a similar manner (De Wever 1985, for the Mesozoic; Takahashi \& Honjo 1981, for the Cenozoic). The assumption that the findings were caused by a double malformation is one of the most plausible interpretations.

\section{Acknowledgements and Funding}

We thank Hui Luo, Bo Xu and Zhaoliang Ma (Nanjing Institute of Geology and Palaeontology, Chinese Academy of Sciences) for their help with this research and the use of a scanning electron microscope. We are also grateful to Taniel Danelian (Editor), Noritoshi Suzuki (reviewer), Galina P. Nestell (reviewer) for critical review and constructive suggestions on this manuscript, which have greatly improved it, and Merlynd K. Nestell for suggestions that improved the English.

\section{Scientific editing by Taniel Danelian}

\section{References}

Anderson, O.R. \& Gupta, S.M. 1998. Evidence of binary division in mature central capsules of a collosphaerid colonial radiolarian, implications for shell ontogenetic patterns in modern and fossil species. Palaeontologia Electronica, 1, 1-13.

De Wever, P. 1985. Sur l'existence, dès le Paléozoïque, de radiolaires siamois. Revue de Paléobiologie, 4, 111-116.

De Wever, P., Dumitrica, P., Caulet, J.P., Nigrini, C. \& Caridroit, M. 2001. Radiolarians in the Sedimentary Record. Gordon and Breach, Singapore.

Dumitrica, P. 2013. Siamese twins and twin-like skeletons in Mesozoic Polycystine Radiolaria. Revue de Micropaléontologie, 56, 51-61.

Itaki, T. \& Bjørklund, K.R. 2007. Conjoined radiolarian skeletons (Actinommidae) from the Japan Sea sediments. Micropaleontology, 53, 371-389.

Ito, T., Kitagawa, Y. \& Matsuoka, A. 2016. Middle and Late Permian radiolarians from chert blocks within conglomerates of the Kamiaso Unit of the Mino terrane in Gifu Prefecture, central Japan. Journal of the Geological Society of Japan, 122, 249-259 [in Japanese with English abstract].

Sugiyama, K. 1992. New spumellarians (Radiolaria) from the Lower Miocene Toyohama Formation, Morozaki Group, central Japan. Bulletin of the Mizunami Fossil Museum, 19, 193-197.

Suzuki, N. \& Not, F. 2015. Biology and Ecology of Radiolaria. In: Ohtsuka, S., Suzuki, T., Horiguchi, T., Suzuki, N. \& Not, F. (eds) Marine Protists: Diversity and Dynamics. Springer, Tokyo, 179-221.

Takahashi, K. \& Honjo, S. 1981. Vertical flux of Radiolaria: a taxon-quantitative sediment trap study from the western tropical Atlantic. Micropaleontology, 27, 140-190. 